\title{
Release of Human Pancreatic Polypeptide and Gastrin in Response to Intraduodenal Stimuli: A Case Report
}

\author{
Aaron S. Fink, John C. Floyd, Jr., and Richard G. Fiddian-Green
}

\begin{abstract}
A recent clinical case afforded an opportunity to study the effects of duodenal stimulation on plasma human pancreatic polypeptide and gastrin concentrations, independent of gastric stimulation. A distension stimulus was provided by rapid injection of $100 \mathrm{ml}$ of water and saline via a T-tube into an isolated duodenal afferent limb. In a third experiment, the saline contained $200 \mathrm{pg} / \mathrm{ml}$ of heptadecapeptide human gastrin. Within $2 \mathrm{~min}$ after each injection, a rapid rise in circulating human pancreatic polypeptide levels appeared that fell promptly towards basal thereafter. Injections of 100 $\mathrm{ml}$ of Flexical, a supplemental tube feeding, resulted in a biphasic human pancreatic polypeptide response, the initial peak comparable to that seen following distension with water, saline, or saline containing gastrin, and a second peak of much greater magnitude and duration followed the initial peak. Plasma gastrin concentrations were not influenced following any of the stimuli. Duodenal distension alone may induce an early transient increase in plasma human pancreatic polypeptide concentrations, while intraduodenal nutrients per se may induce a later increment of greater magnitude and duration.
\end{abstract}

$\mathbf{H}^{2}$ MAN pancreatic polypeptide (hPP), a 36 amino-acid polypeptide of pancreatic origin, ${ }^{1-6}$ increases following gastric distension ${ }^{7.8}$ and after ingestion of a protein meal. ${ }^{36}$ Recently, we had a unique opportunity to investigate the effects of direct stimulation of the duodenum on hPP and gastrin release, independent of gastric stimulation; this article presents the findings of that study.

\section{CASE REPORT}

A 65-yr-old white female was admitted for evaluation of recurrent bilious vomiting. Nine months prior to admission, a $75 \%$ gastrectomy with antecolic Billroth II reconstruction had been performed at an outside hospital for bilious vomiting secondary to "obstruction of the proximal small intestine due to thickened parietal peritoneum across the pancreas and duodenum"; vagotomy had been attempted but not performed due to adhesions from an earlier transthoracic hiatal herniorrhaphy. When her symptoms recurred, she was transferred to University Hospital.

At University Hospital, esophagogastroduodenoscopy revealed patent afferent and efferent limbs; biopsy was normal. A benign pedunculated 7-8-mm diameter sigmoid polyp was removed at endoscopy. When the patient was explored, a small gastric remnant with a slightly elongated afferent loop was discovered. Unexpectedly, a $1 \frac{1}{2}$-inch medial duodenal diverticulum, $1-2$ inches distal to the ampulla, was noted in a markedly hypermotile duodenum. The diverticulum was excised via an anterior duodenotomy, and the duodenum was closed transversely about a $T$-tube for decompression; this afforded direct access to the patient's duodenum.

The patient resumed a normal diet after the first postoperative week. When last seen, 7 mo following surgery, she had continued her excellent course and had gained $20 \mathrm{lb}$ without recurrence of her bilious vomiting.

\section{MATERIALS AND METHODS}

Informed consent and approval of the Institutional Human Use Committee was obtained prior to commencement of the studies. The patient was studied on postoperative days 14 (day 1), 18 (day 2), and 19 (day 3). After she had fasted overnight, a catheter was placed for serial venous sampling and was maintained as a heparin lock: all samples were collected in heparinized tubes. After the duodenum was aspirated, it was then distended by rapidly instilling (within $1 \mathrm{~min}) 100 \mathrm{ml}$ of test solution via the indwelling $\mathrm{T}$-tube (deadspace $5 \mathrm{ml}$ ), and samples of venous blood were collected at $-15,0,2,5,10,20,30,60$, and $90 \mathrm{~min}$; the values obtained at -15 and $0 \mathrm{~min}$ were averaged in determining a basal concentration of hPP. On day 1, Flexical (Doyle Pharmaceuticals, Troy, Mich.), a feeding supplement containing $2.2 \mathrm{~g} / 100 \mathrm{ml}$ protein, $15.4 \mathrm{~g} / 100 \mathrm{ml}$ carbohydrate, and $3.4 \mathrm{~g} / 100 \mathrm{ml}$ fat was used as the distending stimulus. On day $2,100 \mathrm{ml}$ of normal saline was instilled. and then, $90 \mathrm{~min}$ later. $100 \mathrm{ml}$ of normal saline containing $200 \mathrm{pg} / \mathrm{ml}$ of heptadecapeptide human gastrin (G17, Research Plus. Inc., Denville. N.J.) was instilled rapidly. On day 3 , distilled water was instilled.

All blood samples were centrifuged promptly and the plasma separated and frozen. Human pancreatic polypeptide levels were determined by a double antibody radioimmunoassay ${ }^{6}$ using purified hPP and rabbit anti-hPP serum (kindly provided by Dr. R. E. Chance). This assay has previously been shown to be sensitive to amounts of hPP as small as 2 $\mathrm{pg}$, and to be free of cross-reactivity by GIP, VIP. gastrin, CCK. secretin, glucagon, insulin, hGH, or somatostatin." Gastrin concentrations were determined using the commercial kit prepared by Schwarz-Mann Company (Orangeburg. N. Y.) based on the method of Yalow and Berson. ${ }^{9}$ Glucose

From the Depariments of Surgery and Internal Medicine. The University of Michigan Medical Center, Ann Arbor. Mich.

Received for publication June 13, 1978.

Supported in part by U.S. Public Health Service Grant AM-02244

Address reprint requests to Richard G. Fiddian-Green. M.D., Department of Surgery, B3954 CFOB. The University of Michigan Hospitals, 1405 East Ann Street. Ann Arbor. Mich. 48109 .

(c) 1979 by Grune \& Stratton. Inc.

0026-0495/79/2804-0007\$01.00/0 


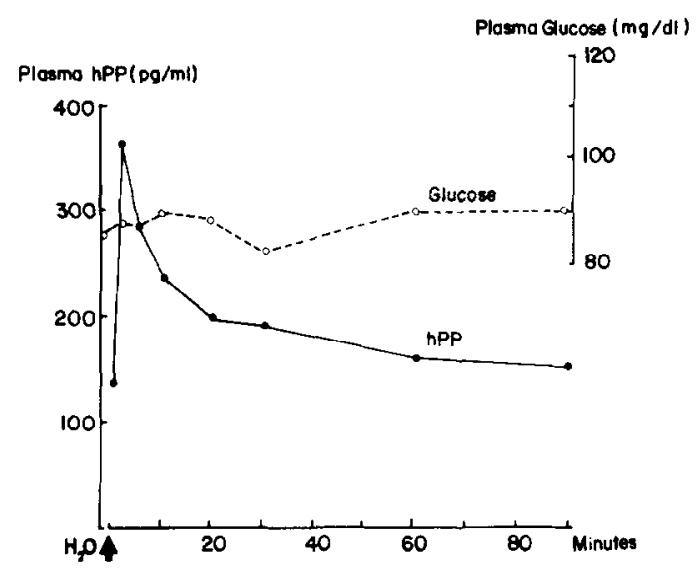

Fig. 1. Response of plasma hPP and glucose to duodenal distension with $100 \mathrm{ml}$ of distilled water (day 3). Basal hPP concentration, $135 \mathrm{pg} / \mathrm{ml}$.

was determined using the commercial kit prepared by Worthington Diagnostics (Freehold. N. J.) based on the method of Slein ${ }^{10}$ as modified by Bondar and Mead."

\section{RESULTS}

Basal hPP and glucose concentrations were consistently normal (hPP normal $=207 \pm 128$ $\mathrm{pg} / \mathrm{ml}$ ) and are indicated in Figs. 1-3. The responses of hPP and glucose to the various duodenal stimuli are also demonstrated. All four stimuli were followed by acute elevations in plasma hPP levels (Figs. 1-3). When the duodenum was distended with water (Fig. 1) or with saline (Fig. 2) there was an immediate increase in plasma hPP concentrations; hPP levels fell rapidly towards basal thereafter. An early increment, comparable in both magnitude and timing to that observed with water and with saline, was observed when the duodenum was distended with Flexical (Fig. 3), but in contrast to the results with water and saline, there followed a second increment of much greater magnitude

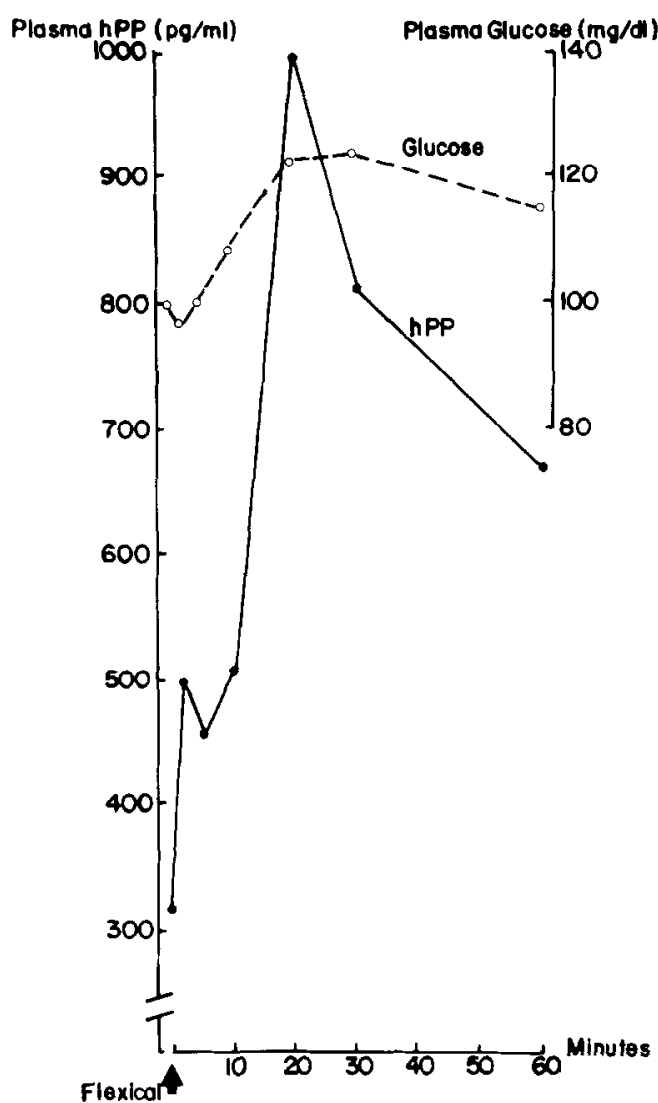

Fig. 3. Response of plasma hPP and glucose to duodenal distension with $100 \mathrm{ml}$ of Flexical (day 1). Basal hPP concentration, $315 \mathrm{pg} / \mathrm{ml}$.

and duration than the first. When the duodenum was distended with saline containing gastrin (Fig. 2), the increases in hPP were similar to those observed with saline or with water.

\section{DISCUSSION}

In the presence of an intact vagus, ingestion of food produces a biphasic release of hPP. ${ }^{8,12,13}$ Gastric distension also causes an acute rise in

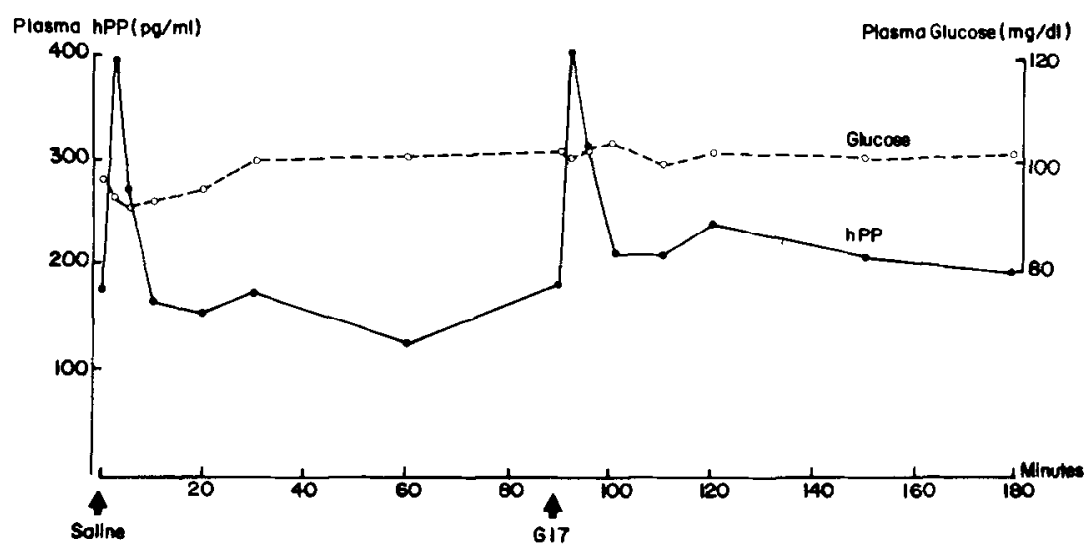

Fig. 2. Response of plasma hPP and glucose to duodenal distension with 100 $\mathrm{ml}$ of normal saline and $100 \mathrm{ml}$ of $617(200 \mathrm{pg} / \mathrm{ml}$ in normal saline; day 21. Basal hPP concentration, $176 \mathrm{pg} / \mathrm{ml}$. 
hPP. ${ }^{8.14}$ Having a tube in this patient's duodenum afforded a unique opportunity to study directly the possible role of the duodenum in the release of hPP without giving mechanical or nutrient stimulation to the stomach at the same time. Rapid injection of $100 \mathrm{ml}$ of fluid into this patient's duodenal afferent limb was used as a distending stimulus. Since the volume infused exceeded the visual estimate of the duodenal capacity at surgery, and since the patient developed mild cramps as the $100 \mathrm{ml}$ was rapidly instilled, we presume that this stimulus produced transient, but distinct, distension of the duodenum. This stimulus was associated with a rapid, but transient, increase in plasma hPP concentrations. Thus duodenal distension alone would appear to release hPP. The response to duodenal distension may have been mediated by either neural or humoral signals, but in view of the rapidity of the response, we presume that it was mediated via neural pathways. In the unlikely event that the Billroth II resection had disrupted vagal pathways to the duodenum and pancreas, a humoral mechanism for the hPP release might then be implicated. It would be difficult to test the integrity of the vagal fibers to the duodenum and pancreas in this patient.

The responses to duodenal distension by water or saline in our study are similar to, but of somewhat greater magnitude than, those reported following gastric distension with saline or glucose, ${ }^{5}$ with celery, ${ }^{14}$ or by a balloon. ${ }^{8}$ These differences could represent a difference in response to gastric versus duodenal stimulation. However, other explanations include more rapid sampling and, hence, detection of an earlier peak than reported previously. ${ }^{\text {? }}$ older age of our patient compared to those reported previously, ${ }^{5-8}$ differences in assay techniques, and simple biologic variation of response. Age may influence the response to distension just as it infuences basal hPP levels. ${ }^{6}$

The later part of the biphasic response, which we observed after the addition of nutrient Flexi$\mathrm{cal}$ to the distending stimulus, is consistent with the suggestion ${ }^{6-8.12,13}$ that the nutrient constituents of a mixed meal act in some manner in addition to distension to stimulate hPP release. This response to nutrient cannot be as clearly localized to the duodenum, since some of the instillate may have refluxed into the stomach through the gastrojejunostomy, contributing to the secondary increment in hPP concentrations seen after Flexical ( $2.2 \mathrm{~g}$ protein). However, we have observed that when 20 times the amount of protein (24 oz of "Sustical"; a tube feeding containing $6.1 \mathrm{~g} / 100 \mathrm{ml}$ protein, $2.3 \mathrm{~g} / 100 \mathrm{ml}$ fat, and $14 \mathrm{~g} / 100 \mathrm{ml}$ carbohydrate) was rapidly ingested by 4 healthy subjects, the rise was less than that which occurred when the $2.2 \mathrm{~g}$ of protein in the Flexical was injected into the duodenum (Floyd, unpublished observation). Since, to date, pancreatic polypeptide cells have been identified in adult man only in the pancreas, the hPP responses observed in this study are evidently pancreatic responses mediated via neural and possibly humoral signals from the duodenum-and perhaps other areas of the upper gastrointestinal tract. $\mathrm{We}^{5,6}$ and others ${ }^{7,8.15,16}$ have pointed to the importance of the gastrointestinal tract in the generation of signals for the pancreatic release of hPP. It would be of interest to determine the effects of vagotomy on the increases of plasma hPP that we have demonstrated to occur in response to acute distension of the duodenum and in response to distension with mixed nutrients. Present techniques of intubation and isolation of duodenal segments should allow the testing of these effects in normal human volunteers and vagotomized patients.

It is of interest to note that the addition of G17 to the distending stimulus did not alter the release of hPP or gastrin. We had added gastrin to the perfusate because of our earlier observation $^{17}$ that in a patient with the Zollinger-Ellison syndrome, distension of the duodenum in a similar manner to that used in this study with $100 \mathrm{ml}$ of water containing $250 \mathrm{pM}(500 \mathrm{pg} / \mathrm{ml})$ of $\mathrm{G} 17$ was followed by a marked rise in serum gastrin concentrations. Distension with water alone in this same patient was followed by a precipitous decrease in serum gastrin levels. In the patient reported in the current study, these stimuli were without effect on serum gastrin.

We conclude, therefore, that intraduodenal stimuli influence plasma hPP concentrations. Duodenal distension alone would appear to release pancreatic polypeptide but not gastrin. Intraduodenal nutrients cause release of hPP similar to that seen after nutrients are ingested. as in a protein meal. These data present preliminary evidence for a duodenopancreatic axis for hPP release. 


\section{ACKNOWLEDGMENTS}

The technical assistance of Silvija Grauds, Sara Kitzsteiner, Gary Burkheiser, and Piyush Kothary is greatly appreciated. We also thank Anita Burck for illustrations, as well as
Ella Schrader for continually reliable and excellent secretarial assistance

\section{REFERENCES}

1. Chance RE: Discussion. Diabetes 21, (Suppl 2):536, 1972

2. Chance RE, Lin TM, Johnson MG, et al: Studies on a newly recognized pancreatic hormone with gastrointestinal activities. 57th Annual Meeting of the Endocrinology Society, 1975, p 183 (abstr)

3. Floyd JC Jr, Chance RE, Hayashi M, et al: Concentrations of a newly recognized pancreatic islet polypeptide in plasma of healthy subjects and in plasma and tumors of patients with insulin-secreting islet cell tumors. Clin Res 23:535A, 1975 (abstr)

4. Floyd JC Jr, Fajans SS, Pek S: Regulation in healthy subjects of the secretion of a newly recognized pancreatic islet polypeptide. Clin Res 24:485A, 1976 (abstr)

5. Floyd JC Jr, Fajans SS, Pek S: Regulation in healthy subjects of the secretion of human pancreatic polypeptide, a newly recognized pancreatic islet polypeptide. Trans Assoc Am Physicians 89:146-158, 1976

6. Floyd JC Jr, Fajans SS, Pek S: A newly recognized pancreatic polypeptide; plasma levels in health and disease, in Greep RO (ed): Recent Progress in Hormone Research, vol 33. New York, Academic Press, 1977, pp 519-570

7. Taylor IL, Richardson CT, Feldman M, et al: Mechianisms of human pancreatic polypeptide (HPP) release. Clin Res 25:574A, 1977 (abstr)

8. Schwartz TW, Rehfeld JF: Mechanism of pancreaticpolypeptide release. Lancet 1:697-698, 1977

9. Yaluw RS, Berson SA: Radioimmunoassay of gastrin. Gastroenterology 58:1-14, 1970
10. Slein MW: D-Glucose determination with hexokinase and glucose-6-phosphate dehydrogenase, in Bergmeyer HV (ed): Methods of Fnzymatic Analysis. New York, Academic Press, 1963, pp 117-123

11. Bondar RJL, Mead D: Evaluation of glucose-6phosphate dehydrogenase from Leuconostoc mesenteroides in hexokinase method for determining glucose in serum. Clin Chem 20:586-\$90, 1974

12. Schwart? TW, Stadil F. Chance RE, et al: Pancreatic-polypeptide response to food in duodenal-uleer patients before and after vagotomy. Lancet 1:1102-1105. 1977

13. Schwartz. TW, Stenquist B, Olbe L: Physiology of mammalian PP and the importance of vagal regulation, in Bloom SR (ed): Gut Hormones. Edinburgh, Churchill Livingston, 1978, pp 261-264

14. Floyd IC Jr, Fajans SS, Pek S: Physiological regulition of plasma levels of human pancreatic polypeptide in man. in Bloom SR (ed): Gut Hormones. Edinburgh, Churchill Livingston. 1978. pp 247--254

15. Adrian TE, Besterman HS, Cooke TJC, et al: Mechanism of pancreatic polypeptide release in man. Lancet 1:161163. 1977

16. Adrian TE, Bloom SR. Besterman HS, et al: PPPhysiology and pathology, in Bloom SF (ed): Gut Hormones. Edinburgh. Churchill Livingsion. 1978, pp 254-260

17. Quinn TJ, Fiddian-Green RG: Luminal gastrin and gastrin relcase. Lancet 2:307-308, 1977 